\title{
Wyprawy na Wschód - literatura współczesna wobec problemu tożsamości
}

\section{Expeditions to the East - present-day literature compared with identity problem}

\author{
|| Agnieszka Czyżak
Uniwersytet im Adama Mickiewicza w Poznaniu
}

\begin{abstract}
The article contains consideration on changes of ways to create pictures of East in Polish literature after the second World War. In the 80s of the twentieth century writers start breaking stereotypes with assitance of intertextuality and subjectivization (e.g. Zostało z uczty bogów by Igor Newerly, Stankiewicz. Powrót by Eustachy Rylski, Drabina Jakubowa by Władysław Terlecki). In the twenty-first century those tendencies increased - an important example is Sońka written by Ignacy Karpowicz, the novel is very popular among young readers.
\end{abstract}

Key words: East, Russia, identity, biography, intertextuality, subjectivization

Streszczenie: Artykuł zawiera rozważania dotyczące przemian w kreowaniu obrazów Wschodu w powojennej literaturze polskiej. W latach 80. XX wieku pisarze zaczęli w rozmaity sposób naruszać istniejące stereotypy, przede wszystkim przez wprowadzanie intertekstualnych gier oraz subiektywizację obrazu (m.in. Igor Newerly Zostało z uczty bogów, Eustachy Rylski Stankiewicz. Powrót, Władysław Terlecki Drabina Jakubowa). W XXI wieku tendencje te zaczęły narastać - wyrazistym przykładem może być Sońka Ignacego Karpowicza, powieść, która zdobyła popularność także wśród młodych czytelników.

Słowa kluczowe: Wschód, Rosja, tożsamość, biografia, intertekstualność, subiektywizacja

W Polsce, kraju leżącym pomiędzy Wschodem a Zachodem, określanie tożsamości (zarówno zbiorowej, jak i jednostkowej) niezwykle często wiązało się z koniecznością ustalenia relacji między polskością a tymi dwoma obszarami tradycji, wzorców, stereotypów. W latach po II wojnie światowej w kreowanych przez kulturę wizjach Wschodu doszło do rozszczepienia - w jej części oficjalnej obowiązywał obraz Związku Radzieckiego jako kraju postępu i siły, równości i świetlanych perspektyw. Jednak poza cenzurą i na emigracji powstawały teksty, których autorzy starali się odsłonić „prawdziwe oblicze” Rosji sowieckiej. Przekazy traumatycznych wschodnich doświadczeń, wspieranych tajoną pamięcią wielu ofiar (dzielących się 
często przeżyciami jedynie z bliskimi), współtworzyły nowy zrąb tradycji w opisywaniu Wschodu.

Wśród silnie eksponowanych emocji dominował strach przed bezwzględnością i brutalną siłą totalitarnego systemu, choć równie silna bywała pogarda dla barbarzyńskiego, zapóźnionego cywilizacyjnie, „zacofanego" Wschodu. Głębokie, sprzeczne afekty leżące u podstaw licznych kulturowych obrazów wschodniej obcości wpływały nie tylko na stosunek wobec Rosjan, ale również na stereotypowe - często pełne niechęci, ambiwalencji, nieufności - postrzeganie mieszkańców wschodnich kresów Polski. Jeśli cechowała ich odmienność etniczna, religijna czy językowa, to fakt ten wzbudzał niejednokrotnie negatywne uczucia lub rodził trudny do przekroczenia dystans wobec dostrzeganej inności.

\section{I}

Teksty takie, jak $\mathrm{Na}$ nieludzkiej ziemi Józefa Czapskiego, Inny świat Gustawa Herlinga-Grudzińskiego, W domu niewoli Beaty Obertyńskiej czy późniejszy Mój wiek, pamiętnik mówiony Aleksandra Wata, wyznaczały sposoby postrzegania systemu stalinowskiego. Wizje Związku Radzieckiego jako państwa totalitarnego, gnębiącego także własnych obywateli, rządzonego strachem i przemocą, zdominowały potoczny ogląd wschodniego sąsiada Polski. Ryszard K. Przybylski w artykule Oblicza Rosji (bolszewickiej) wskazywał jednak na niebezpieczeństwo zbytnich uproszczeń wynikających z prostego utożsamiania Rosji z Sowietami:

Oblicze Rosji zostaje bowiem przesłonięte maską bolszewizmu. Nie Rosję się wtedy widzi, lecz to, co ją przesłania. Następnie jednak przenosi się dostrzeżone na masce cechy na skrywane przez nią oblicze. I wyprowadza określone wnioski. Wtedy nie dostrzega się różnicy między rosyjskim despotyzmem i sowieckim terrorem. Za niekwestionowaną zaletę tekstów, jakie napisali Polacy po opuszczeniu domu niewoli, uznać należy tedy, że w większości przedstawiali raczej bolszewickie realia (Przybylski 2014, 461-462).

Przydarzające się nieraz autorom traumatycznych wspomnień „grzechy" upraszczających generalizacji czy interpretacyjnych nadużyć łatwo wytłumaczyć skalą przeżytego bólu. Emocjonalny bagaż musiał utrudniać obiektywizację doświadczeń.

Znamienny wydaje się fakt, że podobne skutki osobistych doświadczeń obserwować można w tekstach dużo późniejszych. W wydanym na początku lat 90. Imperium Ryszard Kapuściński powziął zamiar spisania zobiektywizowanych relacji ze swoich wizyt w Związku Radzieckim. Książka pisana po przełomie 1989 roku miała stać się zbiorem opowieści, w których resentymenty i niechęć zostaną zastąpione pozbawionym uprzedzeń oglądem realiów. Czytelnicy dostrzegli jednak od razu, że zamysł ten się nie powiódł - przedstawione przez reportera historie pełne były uogólnień i niezrozumiałych emocji. Wyjaśnienie tego stanu rzeczy znaleźć można jednak we wstępie, w którym Kapuściński opowiada o swoim pierwszym spotkaniu z Imperium, w Pińsku, w roku 1939, kiedy wraz z innymi 
uciekinierami usiłował wrócić do miasta, a musieli w tym celu przejść przez kordon strażników:

Trzymają nas na odległość, nie ruszać się! krzyczą i mierzą z karabinów. Mama, a także inne kobiety i dzieci - bo zebrali nas już całą gromadę - płaczą i proszą o litość. Wołajcie o litość, błagają nas nieprzytomne ze strachu mamy, ale co my, dzieci, możemy jeszcze zrobić, i tak już od dawna klęczymy na drodze, szlochamy i wyciągamy w górę ramiona. Krzyk, płacz, karabiny i bagnety, wściekłe twarze spoconych i złych marynarzy, jakaś furia, jakaś groza i niepojętość, to wszystko jest tam, przy moście nad Piną, w tym świecie, w który wkraczam, mając siedem lat (Kapuściński 1993, 11-12).

Przed tym przerażonym siedmiolatkiem były jeszcze lata okupacji oraz powojenne zmiany granic i systemów politycznych - nic dziwnego, że ten trudny czas zdeterminował jego późniejszy ogląd rosyjskiej rzeczywistości.

Pewnym przesunięciom i korektom stereotypowe obrazy Wschodu zaczęły podlegać w latach 80 . Sygnałem zmian w postrzeganiu i opisywaniu Wschodu była autobiograficzna opowieść Igora Newerly Zostało $z$ uczty bogów z roku 1983. Na wstępie autor podał przyczyny podjętego na starość wysiłku spisania własnego - pełnego trudnych doświadczeń - życiorysu: chciał opowiedzieć synowi o jego dziadku. Postanowienie pojawiło się w Dzień Zaduszny, kiedy obaj odwiedzili grób przodka - jak wspomina Newerly - wówczas na cmentarzu wszystko „tchnęło niezmąconą dziwnością, jak grób rosyjskiego oficera, nad którym stoją oto syn i wnuk, pisarze polscy" (Newerly 1983, 7). Z opowieści łatwo zrozumieć skalę problemów z określeniem własnej tożsamości, z jakimi borykał się młody człowiek w targanym przez dziejową zawieruchę kraju.

Bezpośredni świadek wybuchu rewolucji październikowej był zmuszony spoglądać na ludzkie wybory - także własne - jako jednostka, która odczuła przemożną siłę Historii. Newerly podsumowywał:

Przeżyłem dwie wojny światowe i jedną domową, zwycięstwo rewolucji, więzienia sowieckie, polskie, niemieckie, obozy zagłady, dwa ustroje społeczne, które legły na moich oczach, przeżyłem nadzieje, przemiany, dumę, hańbę i klęskę naszego wieku (Newerly 1983, 446).

Historia ukazywana z perspektywy zagubionego w rzeczywistości młodzieńca oraz z punktu widzenia mieszkańców prowincjonalnego miasta nabrała innego, pozbawionego łatwych uogólnień, wymiaru, a pochopne decyzje podejmowane przez pojedynczych ludzi w obliczu nieustannych, trudnych do pojęcia zmian politycznych, społecznych i obyczajowych stawały się w autobiograficznym przekazie bardziej zrozumiałe nawet dla nieobeznanych z historią odbiorców. Zdaniem Przybylskiego działo się tak, ponieważ w utworze najważniejsze są ,jednostkowe relacje, które nie chcą występować w czyimkolwiek imieniu poza własnym" (Przybylski 2014, 466). Podobnym w zamierzeniu i skutkach dziełem okazała się dużo późniejsza autobiografia Karola Modzelewskiego (działacza opozycji o podobnie skomplikowanym 
życiorysie) zatytułowana Zajeździmy kobyłę historii: wyznania poobijanego jeźdźca, wydana w roku 2013, a rok później uhonorowana nagrodą Nike.

Z kolei Eustachy Rylski, pisarz, który debiutował w 1984 roku, we wszystkich tekstach literackich oraz wywiadach odsłaniał swoją fascynację Rosją, rosyjską kulturą i naturą, rosyjską duszą i substancją cielesną. Podtrzymując z reguły stereotypowe ujęcia „rosyjskości”, nieustannie próbował naruszać jej pozycję w obrosłej mitami zbiorowymi, sankcjonowanej przez narodową wspólnotę sferze wartości. Jego bohaterowie osadzani w różnych epokach historycznych - są wśród nich i szwoleżerowie gwardii napoleońskiej, i potomkowie powstańców styczniowych, i współcześni hochsztaplerzy - dręczeni przymusem określania własnej tożsamości, konfrontować ją musieli częstokroć także z tym, co w niej (na różnych poziomach samowiedzy i w najrozmaitszych przejawach) rosyjskie: obce i własne zarazem. Stawali tym samym przed koniecznością rozpoznania granic i wymiarów polskości, dookreślenia jej istoty i własnego do niej stosunku (Czyżak 2014, 501-506).

Swoim debiutem Rylski wyznaczył zakres artystycznych poszukiwań. Bohaterowie dwóch wydanych w jednym tomie minipowieści Stankiewicz oraz Powrót, bez niechęci czy resentymentów noszący mundur wrogiej carskiej armii, postrzegani byli wówczas przez odbiorców jako wzorcowe kreacje antybohaterów. Stankiewicz i Rogoyski, zaprzańcy i odszczepieńcy, moralność identyfikowali z wierną służbą. Mieczysław Orski stwierdzał: „W dziejach liczy się siła, przewaga zbrojna, mir, uważają obaj, Stankiewicz i Rogoyski - i ich zdaniem nie pomogą tu żadne lamenty, pienia tyrtejskie czy złorzeczenia na wschodni reżim" (Orski 2006, 83). Stosunek bohaterów wobec Rosji to po prostu akceptowanie istniejącego stanu rzeczy, przedstawione jako decyzja podjęta świadomie, zrozumiała, a nawet poniekąd oczywista. Natomiast Rosja, choć stereotypowo kojarzona przede wszystkim z brutalną siłą, po zinterioryzowaniu tezy o słuszności wykorzystywania tejże siły dla ekspansji terytorialnej Imperium, stawać się mogła i dla Polaków przestrzenią oswojoną i uznaną za własną. Trzeba tutaj dodać, że w carskiej armii służyło wielu Polaków - w czasach powstania styczniowego ich liczba znacznie przekraczała liczbę powstańców, którzy ruszyli na straceńczy bój z przeważającymi siłami zaborcy (Rakusa-Suszczewski, Szaniawski 2006, 105-108).

Realizacje kolejnych wariantów wciąż od nowa oswajanego kulturowo wizerunku Imperium, dokonywane po roku 1989 dowodzą, iż zmiana perspektywy oglądu jedynie częściowo wpłynęła na podstawowe zasady jego kreowania, tak w wymiarze zbiorowych działań interpretacyjnych, jak i jednostkowych artystycznych wyborów. Maria Janion zwróciła uwagę na prawidłowość organizującą zarówno literackie, jak i nieliterackie procesy wytwarzania obrazów Rosji:

W rzeczy samej „istota” Rosji jest określana - wbrew pozorom - nie jako „istota sama w sobie", lecz poprzez lustrzane przeciwstawienie Europie. To, co w Europie „dobre”, w Rosji przemienia się w „złe” i na odwrót. (...) „Orientalizacja” Rosji 
przez Europę posługuje się stale tymi samymi bliźniaczymi, lustrzanymi odbiciami. Niejednokrotnie podlegały one dekonstrukcji, która jednak jakoś nie docierała do polskiej świadomości (Janion 2007, 195).

Szczególnie wyraźnie widać tę prawidłowość w napisanej dwie dekady później powieści Rylskiego - w wydanym w roku 2004 Warunku, historii dwóch dezerterów armii napoleońskiej, którzy przemierzyć musieli długą drogę do domu przez mroźne pustkowia Imperium. Polacy, Hoszowski i Rangułt, wyruszyli spod Moskwy w przeddzień klęski wojsk Napoleona, by okrężną drogą dotrzeć na rodzinną Litwę. Głód, zimno, strach zarówno przed pościgiem wysłanym przez „swoich”, jak i spotkaniem z wrogiem, sprawił, iż uciekinierzy całą energię życiową skupić musieli na przetrwaniu kolejnych dni koszmaru.

Spotkali również na swojej drodze nieszczęśników z innych formacji, być może również dezerterów. Sześć zamarzniętych na śmierć ciał żołnierzy piechoty neapolitańskiej stało się podwójnym znakiem: dla zbiegów byli ratunkiem, mogli obedrzeć trupy z ubrań, ograbić z resztek jedzenia. W szerszym planie włoscy piechurzy okazali się naiwnymi słabeuszami, których pokonała niemożliwa do oswojenia przestrzeń:

\begin{abstract}
Sztywni, biali, wyzwoleni. Zapłacili cenę dwóch nieostrożności. Pierwszej, że zgłosili się na rosyjską wyprawę, i drugiej, że swoją ostatnią noc spędzili w głębokiej rozpadlinie, w której zebrała się bagienna, mroźna mgła, wygaszająca ognisko i życie. Te dzieci południowej łagodności nie miały szans w zderzeniu z kontynentalnym bestialstwem, które zabiło ich, samo najpewniej zaskoczone łatwością, z jaką mu to przyszło (Rylski 2005, 149).
\end{abstract}

Ludzi z Południa zabijał lodowaty, pusty kosmos, obojętny na ich nieprzystosowanie. Polacy przeżyli - jak sugeruje Rylski - bowiem przynależeli do zimnych przestrzeni Wschodu: „Cokolwiek by rzec o peregrynacji Hoszowskiego i Rangułta, to w jakimś stopniu byli u siebie. Zamęczał ich własny świat" (Rylski 2005, 149).

Rylski zatem po raz kolejny kreując obraz potęgi Rosji i grozę jej lodowatych pustkowi, swoich bohaterów umieścił wewnątrz przestrzeni wrogiej, lecz zarazem specyficznie własnej. Udało mu się tym samym ominąć jedną z pułapek na drodze do tworzenia obrazów nowej, postzależnościowej tożsamości zbiorowej, którą tak charakteryzowała Maria Janion:

europeizacja Europy Środkowej posługuje się monolitycznym obrazem Innego-Rosji, oddziela się od Wielkiej Pustki na Wschód od siebie i stwarza intelektualną i moralną przegrodę między „nami” a „nimi”, nie pomnąc (...) na niepokojącą bliskość „nas” i „ich” (Janion 2007, 235).

Z drugiej jednak strony w powieści Rylskiego owa „bliskość między nami a nimi” przestaje być niepokojąca, staje się konieczną do zaakceptowania konstatacją stanu rzeczy. Interesujący wydaje się fakt, iżjedynymi Rosjanami dokładniej pokazanymi w utworze są żołnierze tworzący oddział świetnie wyszkolonej jazdy. Ich dowódca - jakby żywcem przeniesiony z kart powieści 
Tołstoja - tak zareagował na wygłoszone przez Rangułta (wówczas odzianego w łachmany, wygłodzonego nieszczęśnika) zdanie w języku francuskim:

Przeżegnał się szerokim prawosławnym krzyżem i wyszeptał: Rosja jest wielka i święta, a lud jej nie przestanie mnie zadziwiać. I gdy poprosił Wadima, by wydał rozkaz marszu, jego otwartą, chłopięcą jeszcze twarz zagrzała radość, a szkła binokli zwilgotniały od łez (Rylski 2005, 141).

Spotkanie grożące uciekinierom śmiercią stało się tym samym groteskową grą pozorów, w której polscy dezerterzy z wrogiej Rosjanom armii zostali uznani za niezwykłe okazy „rosyjskiego ludu”, poświadczające sakralizowaną wielkość Imperium.

Walka Zachodu ze Wschodem staje się $\mathrm{w}$ wariancie Rylskiego grą i z nieprzewidywalnym, a zatem niepojmowalnym, jawiącym się jako niespójny i zwodniczy, zachodnim światem i jednocześnie z budzącą grozę, a jednak oswojoną, zrozumiałą, jak zawsze niezmienną polityką wschodniego ciemiężcy. Polak, skazany na bycie „pomiędzy” traktowanym nieufnie Zachodem a groźnym Wschodem okazuje się nieuchronnie człowiekiem skazanym na ciągły trud konstruowania własnej tożsamości z dostępnych wzorców - najczęściej będącego mieszaniną obu tradycji, tworzoną zgodnie z jednostkowym zapotrzebowaniem.

W roku 1988 Władysław Terlecki, znany przede wszystkim z wcześniejszej serii powieści rozgrywających się w czasach powstania styczniowego, opublikował powieść Drabina Jakubowi albo podróż. W swojej podszytej gorzkim sarkazmem grotesce pisarz przedstawił dzieje wyprawy dwóch szpiegów, polskiego hrabiego i jego służącego karła Aleksandra, którzy za czasów panowania ostatniego króla Polski, Stanisława Augusta Poniatowskiego, wyruszyli do Rosji. Terlecki dokonał w swoim utworze intrygującej dekonstrukcji wzorca zachodnich opowieści o wojażach na Wschód, jakimi przez wiele dziesięcioleci były Listy z Rosji Astolphe’a de Custine, napisane w roku 1839. W tej podróżniczej opowieści francuski arystokrata spisał swoje doświadczenia z wizyty w Rosji, rządzonej wówczas przez cara Mikołaja I. Dziewiętnastowieczny tekst piętnował wszelkie wynaturzenia zarówno rosyjskiego systemu, jak i obyczajowości, w dodatku bez najmniejszej troski o zobiektywizowanie przekazu. Pod piórem człowieka wychowanego w kulturze zachodniej miażdżącej krytyce poddany został despotyzm władz i państwowa biurokracja oraz dzikość, zacofanie czy nawet barbarzyńskie obyczaje ludu.

We współczesnej powieści bohaterowie Terleckiego, również oswojeni z kulturą Zachodu (wówczas przede wszystkim francuską odmianą libertynizmu) zderzeni zostali $\mathrm{z}$ brutalnością Wschodu. Jednak ich cywilizacyjna edukacja nie okazała się wystarczającą obroną przeciw bezwzględnej sile mieszkańców Rosji. Z kolei wyrastający we wschodniej kulturze obywatele Imperium tak naprawdę okazali się słabi i ulegli wobec władzy swoją fizyczna przewagę kierowali bez wahania przeciw obcym, słabszym, 
ułomnym, jednak byli zawsze gotowi na służalczą uległość wobec „swoich", o ile ci mieli wyższą rangę społeczną. Rządzący natomiast sprawnie wykorzystywali ciemnotę ludu, jego skłonność do zabobonów i niechęć do wykraczania choćby myślą czy wyobraźnią poza ciasne terytorium miejsca urodzenia.

Podróżnicy z Zachodu (czy raczej agenci prowadzący tajną misję) nie mieli żadnych szans w starciu ze złowrogą siłą carskiej Rosji - tak jak sportretowany ironicznie Stanisław August nie miał żadnych szans w swojej grze z Katarzyną II. Cywilizacyjna wyższość pozwalała wędrowcom spoglądać na tubylców z lekceważeniem czy nawet pogardą, jednak tylko na początku podróży. Później poczucie kulturowej przewagi ustąpić musiało coraz bardziej nasilającym się uczuciom lęku, beznadziei, zagubienia w niezmierzonych i coraz bardziej niemożliwych do ogarnięcia (oświeceniowym) rozumem, przestrzeniach.

Z racji pochodzenia hrabiego i jego sługi na kartach powieści pojawił się problem Polski, kraju już wówczas jedynie buforowego, z ograniczoną suwerennością, państwa miażdżonego przez dwie potęgi Wschodu i Zachodu. Jeden z bohaterów, Włoch, twierdził z przekonaniem:

Nawet afery mają tu jakiś paskudnie prowincjonalny wymiar. Walka toczy się o sprawy w istocie mało ważne. Kiepskie kariery. Liche pieniądze (...). Jedni umierają z przeżarcia. Inni znów z głodu. Wszystko kręci się wokół brzucha. Stąd też umysły tubylców (...) są tak nieznośnie gnuśne. Nie stać ich już na wielki zryw. Nawet teraz, gdy nad krajem gromadzą się tak groźne chmury (Terlecki 1988, 25).

Polska jako kraj „tyleż paskudny, co i nieszczęśliwy” nie będzie zatem miała szans na obronę granic, także dlatego, że jej obywatele utracili wiarę w sens walki o przetrwanie wspólnoty. Ich zbiorowa tożsamość przestała wówczas służyć za tarczę przeciw wrogom - dla wielu jednostek zaczynał się czas świadomego odrzucania przynależności do polskiej tradycji.

II

Wypróbowane w latach 80. sposoby nawiązywania literackiego dialogu z funkcjonującymi nadal stereotypowymi obrazami Wschodu - subiektywizacja perspektywy oglądu oraz intertekstualne gry - mają swoją kontynuację w literaturze najnowszej. Warto w tym miejscu przyjrzeć się bliżej powieści Ignacego Karpowicza Sońka, opublikowanej w 2014 roku. W tej opowieści - intymnej i intertekstualnej zarazem - spotkanie młodego reżysera Igora, odnoszącego sukcesy w dużym mieście, z prostą chłopką mieszkającą na wschodnich kresach Polski, doprowadza z jednej strony do polemicznej rewizji tradycyjnych obrazów wschodniości, kresowości, chłopskości, z drugiej do osobistego wyznania.

W utworze Karpowicza przypadkowy postój „miastowego” w zapadłej wiosce na wschodnich rubieżach kraju zmienia się w wędrówkę w przeszłość - odsłaniającą historię dożywającej swych lat starej wieśniaczki z czasów jej młodości - oraz w głąb: ku najskrytszym zagadkom tożsamości 
narratora. Sońka, która opowiada o swoich losach z czasów II wojny światowej, określa siebie jako „tutejszą”, obce są jej problemy związane z innymi sposobami wyrażania przynależności do wspólnoty. Z kolei Igor okazuje się $\mathrm{w}$ istocie Ignacym, urodzonym w nieodległej wsi chłopcem, który odrzucił swoją „gorszą" tożsamość i język (oraz, jak wspomina, wiarę w „gorszego" Boga), by wieść życie „cywilizowanego” mieszkańca stolicy, ukrywającego przed wszystkimi swe wschodnie korzenie. Powrót do miejsca narodzin zmusił go jednak do rewizji podejmowanych wcześniej wyborów.

Akt rekonstrukcji miejsc utraconych, zapomnianych, startych z aktualnych map, z reguły nie jest dziś próbą nakreślenia melancholijnych czy nostalgicznych pejzaży przeszłości, lecz odsłania odmienne przeznaczenie. Przestrzeń kreowana w takich tekstach staje się specyficznym „miejscem autobiograficznym" (Czermińska 2011, 183-189) autora, zaanektowanym i zinterioryzowanym w akcie twórczej ekspresji i autorefleksji. W miejscu poddawanym uważnemu, ale silnie subiektywizowanemu oglądowi, dochodzi do wielorakich przekształceń obrazów potocznej pamięci przeszłości oraz jej utrwalonych w tradycji wizji. Cywilizacyjna katastrofa, która doprowadziła do gruntownego przeobrażenia znanego nam świata, pozostawiła puste miejsca domagające się wypełnienia, odtworzenia, przede wszystkim zaś podjęcia próby zrozumienia przebiegu minionych zdarzeń i wejścia w osobistą, osadzoną w aktualnych realiach, relację z przeszłością - jej śladami, znakami, cieniami.

Historia II wojny światowej okazuje się wciąż niedostatecznie rozpoznana. Marek Zaleski, przypominając głęboko zakorzenione w świadomości zbiorowej przekonanie, iż „umarli niepogrzebani należycie - wracają” (Zaleski 2007, 46), wskazywał na przyczyny cząstkowej jedynie reprezentacji traumatycznych doświadczeń wojny w literaturze powstającej w okresie następującym po jej zakończeniu. Umarli nie mogli znaleźć odpowiedniego miejsca w tekstach, bo silniejszy okazywał się mechanizm zapomnienia służący życiu, wzmacniany przez rzeczników zwycięskiej wówczas ideologii. Utraceni bliscy okazywali się też na rozmaite sposoby „niesłusznymi” umarłymi, o których należało zapominać dla własnego bezpieczeństwa czy choćby spokoju. Przede wszystkim jednak: „umarli nie mogli znaleźć swego miejsca, bo piszący mieli świadomość niewydolności języka i jego wadliwych reprezentacji w obliczu tego, czym była wojenna i okupacyjna śmierć, szczególnie w swej nowej postaci" (Zaleski 2007, 44). Istotnym aspektem utrzymywania sfer niepamięci w obrazowaniu wojny okazał się też długo usuwany ze sfery świadomości zbiorowej fakt, iż w czasach PRL-u starano się zniekształcać obraz problemów wynikających z wieloetnicznego statusu II Rzeczpospolitej oraz ukrywać konsekwencje, jakie ten fakt miał w czasach okupacji.

W XXI wieku, w warunkach rozpadu wszelkich mitów spajających wspólnotę, literackich rozliczeń z przeszłością można dokonywać przede wszystkim jako jednostkowo przeprowadzanych rozpoznań, czynionych we 
własnym imieniu. Dlatego opowieść rozgrywająca się w Królowym Stojle skupia się na jednostkowo przeżywanej historii, pojedynczym doświadczeniu przekształcanym w subiektywizowaną narrację, prowadzoną z punktu widzenia człowieka na wskroś współczesnego. Narrator wielekroć, najczęściej autoironicznie, ujawnia kreacyjny wymiar opowieści:

muszę położyć nacisk na uniwersalny charakter tej historii, tej opowieści, którą przeczuwam, lecz której jeszcze nie poznałem. Ta historia musi być zrozumiała przede wszystkim dla innych, wtedy stanie się zrozumiała też dla mnie (Karpowicz 2014, 34).

Narracja o losach dotkniętej traumą wojenną Sońki szybko okazuje się relacją o jednoczesnym poznawaniu i przetwarzaniu jej losów, prowadzącym nie do zrozumienia przeszłości, lecz eksplikowania teraźniejszości i własnego w niej miejsca. Narrator-bohater wkracza w przestrzeń cudzą, która okazuje się na poły własną, niegdyś odrzuconą, dziś odzyskiwaną. W miarę rozwoju opowieści to właśnie gesty wiodące do samopoznania kondycji twórcy okazują się nadrzędnym celem artystycznych działań.

Tekstowe sygnały, które można odnaleźć w Sońce Karpowicza, prowadzą do zdekostruowania realności wojennej historii. Mowa w nich także o ocaleniu - jednak nie pamięci o przeszłości, lecz „ocalaniu siebie”. Kiedy narrator Sońki zdaje sobie sprawę, że musi „zapamiętać więcej” niż zostało opowiedziane, zaczyna rozumieć także, iż „musi pamięć zaprząc w teatralny lub powieściowy kierat, by siebie ocalić, by wreszcie opowiedzieć jakąś prawdę, zawalczyć o coś" (Karpowicz 2014, 59). Inaczej mówiąc, musi -jako przedstawiciel pokolenia niepamiętającego czasów okupacji - zamknąć traumatyczne doświadczenia wojenne w znany, oswojony kształt, a jednocześnie wytworzyć ocalający twórcę dystans i odsłonić piętra samoświadomości, także te aktualnie, równolegle z tworzeniem opowieści, dobudowywane. Ujawniane sygnały aktu tworzenia narracji o wojennych losach bohaterów zderzane są z gorzką świadomością ograniczeń wynikających z rzeczywistego przebiegu historycznych wydarzeń.

W Sońce tematyzowaniu podlegają reguły przepisywania cudzego losu dla własnych celów - przede wszystkim autokreacyjnych. Celem artystycznych zabiegów stać się musiało zatem odkrywanie i jednoczesne wytwarzanie tożsamości własnej, ustanawianej w relacji z minionym czasem i w odniesieniu do utraconych przestrzeni, trudne dążenie do samopoznania. Nasza tożsamość - jak przekonuje Zaleski - może być zakładnikiem opowieści. O innej Soni, bohaterce Tworek Marka Bieńczyka, powiedział:

To, co jest ostatecznym celem (obecność), w literaturze jest śladem (przedstawienie). Być, to stawać się poprzez coraz to bardziej mnożące się znaki - ślady obecności. Im więcej znaków, tym silniejsze bycie. Powrót Soni dokonujący się w geście pisania jako pracy żałoby jest procesem wzrostu, przyrastania sensu, reintegracji własnej osobowości i tożsamości (Zaleski 2007, 3008).

Podobną drogę obrał Karpowicz, który reintegrację osobowości i tożsamości dokonującej się w akcie tworzenia uczynił osią swojego utworu. 
Pozostawił także liczne tropy pozwalające doszukiwać się w postaci Igora-Ignacego śladów autora.

Niezwykle często pojawia się w Sońce nazwa miejscowa Królowe Stojło, brzmiąca zarazem obco i baśniowo. Składająca się z czterech domostw wieś „na końcu świata” istnieje poza zasięgiem cywilizacji. Idylliczny z pozoru pejzaż przesłania jednak mroczną, naznaczoną śmiercią „istotę” krajobrazu. „Królewicz”, który znalazł się tam niezamierzenie, od początku wyczuwa ową niejednorodność przestrzeni:

Coś mu się boleśnie przypominało. Krajobraz wyglądał jak krajobraz, wszystko wyglądało, jak wyglądało, łąka i drzewa, mimo to cała ta przyroda, rzeka i niebo, droga i bociany, cała ta przyroda zawierała w sobie jakąś groźbę. Usiłował rozstrzygnąć, czy to groźba z przeszłości, czy może na przyszłość (Karpowicz 2014, 15-16).

Zapowiadana przez początkowe sceny opowieść o zderzeniu miejskiego z wiejskim, o przypadkowym spotkaniu niezdarnego mieszczucha z nieznającą świata wiejską starowiną, rozwija się zrazu w przewidywanym kierunku. Bohater wkracza w przestrzeń Sońki ostrożnie, z oporami, jakby przekraczał próg obcego świata. Wkrótce jednak udaje mu się „zadomowić", a raczej odzyskać zdolność zadomowienia się w przestrzeni dzieciństwa, odrzuconej na progu dorosłego życia.

Podjęcie rozmowy prowadzi w sposób naturalny do wspólnego posiłku, noclegu pod jednym dachem, wzajemnego wkraczania w granice intymności - jak wówczas, kiedy Igor usiłuje rozczesać resztkę włosów Sońki. Punktem kulminacyjnym powieści stało się samotne czuwanie warszawskiego reżysera nad konającą staruszką, która po wyartykułowaniu swojej ostatniej spowiedzi może odejść. Komu jednak ją pozostawia? Czy sprawnemu rzemieślnikowi, który będzie umiał ją wykorzystać, by „wzruszyć” publiczność, czy też bliskiemu, swojakowi, tutejszemu, potrafiącemu nie tylko lepiej ją zrozumieć, ale i odnaleźć w niej siebie? Kim pozostanie ona sama: bohaterką tragicznego romansu, starą wiedźmą czy opuszczoną przez wszystkich ofiarą dziejowej zawieruchy?

Niezobowiązująca pogawędka Igora/Ignacego z goszczącą go kobietą zmieniła się przecież w mozolne odtwarzanie traumy przeszłości, której nie unieważniło relacjonowanie przebiegu aktu kreacji i wskazywanie piętrzących się na obranej drodze pułapek. Młoda chłopka z pogranicza i jej kochanek esesman są parą niemożliwą do zaakceptowania w żadnym miejscu i czasie, a ich wspólna historia nie mogła mieć jakiegokolwiek „szczęśliwego" zakończenia. Zaznająca pierwszy raz w życiu miłości Sońka nie przestawała jednak kochać tego, którego powinna odrzucić jako wroga, nawet wtedy, gdy pojęła rozmiar jego zbrodni. Justyna Sobolewska stwierdziła wprost: „nie da się dziś tak po prostu opowiadać takich historii, wszystko jest dyskursem, który można dowolnie kształtować. Narrator odsłania więc przed czytelnikiem całą machinę przekształcania cierpienia i śmierci we wzruszenie" (Sobolewska 2014, 80). Narrator jednoznacznie wyraża brak złudzeń - swój i nie zawsze tożsamego z nim bohatera-reżysera. 
Przyzwyczajony do manipulowania wzruszeniami odbiorców reżyser nie potrafi już odzyskać poczucia autentyczności:

Czuł się jak kustosz w muzeum cudzych wspomnień, jak horolog przy rozłożonym mechanizmie. Dopiero, gdy się przełożyło te wspomnienia na własne doświadczenie, wyłaniało się coś zrozumiałego, jednocześnie jednak jasne stawało się to, że po drodze coś umykało. Autentyczność to jednak potworna klisza (Karpowicz 2014, 108).

Poszukiwanie śladów przeszłości, próba ich transpozycji okazuje się jednak ostatecznie kolejnym zadaniem niemożliwym do wypełnienia - nawet po sprzęgnięciu ich z materią własnych doświadczeń. Być może więc jedynym, co pozostaje, jest nieustanne poszukiwanie - nie tyle jednoznacznych odpowiedzi, ile sposobów „wysłowienia”. Jak się zdaje, Karpowicz uczynił tę wiedzę ośrodkiem swojego utworu, za cel zaś postawił sobie podjęcie (kolejnej w długim szeregu) próby artystycznego przezwyciężenia ułomności reprezentacji, niedającej pełnego dostępu do istoty doświadczeń ani do tajników zbudowanej na ich podstawie tożsamości.

Znikają dziś ostatnie ślady żywych kresowych tradycji, odchodzą ostatni świadkowie trudnej historii wschodniego pogranicza, znikają nie tylko przedmioty, pamiątki, relikty przeszłości, w niepamięć odchodzi też język: pieśni, obrzędy, baśnie, legendy. Koncepcje śladu, definiujące pojęcie jako formę obecności tego, co minione, zapomniane, wymykające się przedstawieniu lub utracone, wskazują nie tylko na związki śladu z kategorią pamięci jednostkowej czy zbiorowej, ale i na jego immanentną niespójność oraz permanentną niestabilność. Utrwalane mimo to w niezliczonych tekstach kultury zdradzają wówczas swą podatność na zawłaszczanie w ramach rozmaitych dyskursów i tendencję do zastygania w doraźnie przydatnych kształtach. Ironia i autoironia, często też podszyty goryczą sarkazm, z reguły towarzyszą twórcom udającym się na literackie wyprawy do miejsc z nieodległej przeszłości, a jednak ostatecznie utraconych, startych z powierzchni ziemi, pozostających cudzą przestrzenią, niemożliwych do odzyskania w opowieści. Eksploracja tych miejsc prowadzi dziś niejednokrotnie do zastąpienia prezentacji tego, co musi pozostać cudze i trudne do oswojenia, wyrazistymi gestami samopoznania, rodzącego się w akcie twórczym.

Znaczący wydaje się fakt, że powieść Karpowicza stała się utworem popularnym szczególnie wśród młodych odbiorców, co potwierdzają doświadczenia dydaktyki akademickiej. Można przypuszczać, że podstawową przyczyną tej poczytności stała się emocjonalna warstwa utworu. Stojących u progu dorosłości czytelników zachwyciła i poruszyła opowieść o inności, cierpieniu, wykluczeniu, bo w intencji autora kryło się przesłanie, by niestrudzenie uczyć się poszanowania dla odmienności, akceptowania różnic między ludźmi, uznawania autonomii jednostkowego przeżywania świata. Zdolność rozumienia innych doprowadzić może do głębszego poznania siebie oraz ułatwić określenie granic i istoty własnej tożsamości - a tym samym umożliwić odnalezienie własnego miejsca w świecie. 


\section{Bibliografia:}

Custine Astolphe de, 1995, Listy z Rosji, Czermińska K. (przeł.), Warszawa.

Czermińska Małgorzata, 2011, Miejsce autobiograficzne. Propozycja $w$ ramach geopoetyki, „Teksty Drugie”, nr 6, s. 178-202.

Czyżak Agnieszka, 2014, „Dla Rosjan literatura jest najważniejsza”. Eustachego Rylskiego rozliczenia z przeszłościa, w: Obrazy Rosji w literaturze XX wieku, Jarzyna A., Kopeć Z. (red.), Poznań, s. 499-511.

Janion Maria, 2007, Niesamowita Słowiańszczyzna, Kraków.

Kapuściński Ryszard, 1993, Imperium, Warszawa.

Karpowicz Ignacy, 2014, Sońka, Kraków.

Modzelewski Karol, 2013, Zajeździmy kobyłę historii: wyznania poobijanego jeźdźca, Warszawa.

Newerly Igor, 1983, Zostało z uczty bogów, Warszawa.

Orski Mieczysław, 2006, Rozbite zwierciadło. Krytyczny przewodnik po gościńcach nowej prozy, Wrocław.

Przybylski Ryszard K., 2014, Obrazy Rosji (bolszewickiej), w: Obrazy Rosji w literaturze XX wieku, Jarzyna A., Kopeć Z. (red.), Poznań, s. 459-468.

Rakusa-Suszczewski Stanisław, Szaniawski Hubert, 2006, O Polakach $w$ armii carskiej Rosji, „Nauka”, nr 4, s. 101-110.

Rylski Eustachy, 1984, Stankiewicz. Powrót, Warszawa.

Rylski Eustachy, 2005, Warunek, Warszawa.

Sobolewska Justyna, 2014, Zdrajczyni, dziwka, szeptucha, „Polityka”, nr 2958, s. 80-81.

Terlecki Władysław, 1988, Drabina Jakubowa albo podróż, Warszawa.

Zaleski Marek, 2007, Echa idylli w literaturze polskiej doby nowoczesności i późnej nowoczesności, Kraków.

\section{O Autorce:}

Agnieszka Czyżak - dr hab., prof. UAM w Zakładzie Poetyki i Krytyki Literackiej IFP UAM. Zainteresowania badawcze: historia literatury współczesnej ze szczególnym uwzględnieniem literatury powstałej po roku 1989 oraz teoria literatury, przede wszystkim przemiany i rozwój badań kulturowych. Współredaktorka tomów zbiorowych Powroty Iwaszkiewicza (1999), Wariacje na temat (2003), Ulotność i trwanie (2003) PRL - świat (nie)przedstawiony (2010), Elementy do portretu. Szkice o twórczości Aleksandra Wata (2011), Pokolenie „Współczesności”. Twórcy. Dzieła. Znaczenie (2016). Autorka książek: Życiorysy polskie 1944-89 (1997), Kazimierz Brandys (1998), Na starość. Szkice o literaturze przełomu tysiacleci (2011), Świadectwo rozproszone. Literatura najnowsza wobec przemian (2015) oraz Przestrzenie w tekście, w przestrzeni tekstów. Interpretacje (2018). 